\title{
POPULARITAS POLITIKUS: ANTARA KERJA POLITIK ATAU KEHEBATAN TELEVISI
}

\author{
Rahmat Edi Irawan \\ Marketing Communication Department, Faculty of Economic and Communication, BINUS University \\ Jln. KH. Syahdan No.9, Palmerah, Jakarta Barat 11480 \\ reirawan@yahoo.co.id
}

\begin{abstract}
Popularity is coveted by politicians before general election. Politicians who have high popularity have a much larger capital to be successfully elected in general election. In contrast, ordinary or even low popularity will be difficult for politicians to win public institution seats contested. The problem is about how to increase the popularity for politicians. This paper discusses about relationship between the popularity of politicians with political work and the greatness of television, whether it is true that the increase in popularity of politicians can only be done with political work, or in the contrary, the increase in the popularity of politicians can be done with the use of television media, as the media are most widely used in the community. Discussion of this paper was done using literature study obtained from political communication and mass communication books related to this matter. In addition, data from recent news media, especially regarding the popularity of the politicians, political work and the use of television media in general elections were also used to enrich this paper. Result of this literature study concludes that popularity of the politicians has become a major requirement for politicians to succeed in general election. Popularity of the politicians is synonymous with political work. Political work done continuously in approaching the constituent is the way to boost the popularity. Nevertheless, the political work is not enough. Currently, efforts to boost popularity needs mass media, especially television, which can introduce politicians to their constituents who are also the television audience.
\end{abstract}

Keywords: popularity of the politicians, political work, television

\begin{abstract}
ABSTRAK
Popularitas menjadi kata yang paling didambakan para politikus menjelang pemilihan umum. Politikus yang punya popularitas tinggi mempunyai modal yang jauh lebih besar untuk sukses terpilih dalam pemilihan umum. Sebaliknya, popularitas yang biasa-biasa saja atau bahkan rendah bisa jadi akan menyulitkan para politikus untuk merebut kursi institusi publik yang diperebutkan. Permasalahannya adalah cara meningkatkan popularitas bagi para politikus tersebut. Tulisan ini membahas tentang kaitan antara popularitas politikus dengan kerja politik dan kehebatan televisi. Apakah benar memang peningkatan popularitas politikus hanya dapat dilakukan dengan kerja politik; atau sebaliknya, kenaikan popularitas politikus bisa dilakukan dengan penggunaan media televisi, sebagai media massa yang paling banyak digunakan di masyarakat. Pembahasan tulisan ini dilakukan dengan menggunakan studi literatur. Data diperoleh dari buku komunikasi politik dan komunikasi massa yang terkait dengan pembahasan materi. Data terbaru dari berita di media massa terutama yang berkaitan dengan popularitas politikus, kerja politik dan penggunaan media massa televisi dalam pemilihan umum lalu juga digunakan untuk memperkaya tulisan ini. Hasil studi literatur menunjukkan bahwa popularitas politikus memang menjadi persyaratan utama bagi para politikus untuk sukses di pemilihan umum. Popularitas politikus memang identik dengan kerja politik. Sementara kerja politik mendekati konstituen secara terus menerus adalah cara yang harus dilakukan para politikus untuk mendongkrak popularitas. Meskipun demikian, kerja politik saja tidak cukup. Saat ini upaya mendongkrak popularitas juga perlu dilakukan dengan menggunakan media massa, terutama televisi, yang dapat memperkenalkan para politikus kepada para pemilihnya yang juga penonton televisi.
\end{abstract}

Kata kunci: popularitas politikus, kerja politik, televisi 


\section{PENDAHULUAN}

Menjelang pemilihan umum 2014, seperti biasanya masalah popularitas menjadi salah satu masalah paling krusial yang dihadapi para politikus. Tokoh dan aktivis politik yang sedang berlombalomba untuk dipilih menjadi anggota parlemen, baik di pusat maupun daerah, memang amat bergantung pada popularitas mereka untuk dapat terpilih. Mereka yang populer tentu saja punya potensi yang lebih besar untuk dapat terpilh menjadi wakil rakyat. Sementara untuk mereka yang tidak begitu dikenal, tentu harus kerja keras untuk mengerek popularitas yang masih amat rendah. Popularitas seakan menjadi harga mati bagi para politikus untuk mengerek kesuksesan bagi mereka pada saat pemilu ini.

Meningkatkan popularitas tentu bukan hal yang mudah. Sejak lama, kerja politik, atau upaya yang dilakukan terus menerus para politikus untuk mendekati para konstituen secara langsung, memang diyakini sebagai cara untuk menaikkan popularitas. Dekat dengan konstituen akan membuat mereka makin dikenal para pemilih. Apalagi jika ditambah dengan kemampuan para politikus membantu atau menyelesaikan masalah yang dihadapi oleh para konstituen, mereka akan makin dikenal juga. Atau dengan kata lain, jika para politikus tersebut makin dikenal, berarti popularitas para politikus tersebut akan makin terkerek juga.

Saat ini, selain kerja politik seperti yang telah disebutkan, penggunaan media massa untuk mengerek popularitas juga makin umum dilakukan para politikus. Meski harganya tidak murah, banyak politikus yang berani beriklan untuk menaikkan pamornya atau popularitasnya. Tidak cukup dengan iklan, item berita bahkan acara-acara hiburan di televisi, juga mulai diisi dengan para politikus yang berupaya untuk menaikkan popularitas. Tidak heran jika masalah penggunaan media massa (khususnya televisi) untuk meningkatkan popularitas politikus, termasuk pencitraan politik yang dilakukan para politikus, menjadi salah satu kajian bidang komunikasi massa atau komunikasi politik yang cukup banyak dilakukan dan dipubilikasikan, tidak saja di Indonesia, tetapi juga di negara-negara lain.

\section{Permasalahan}

Adapun permasalahan yang bisa diangkat dalam permasalahan popularitas politikus dengan kerja politik dan kehebatan televisi adalah sebagai berikut. Pertama, bagaimana hubungan antara popularitas politikus dengan kerja politik dan kehebatan media televisi. Kedua, bagaimana pengaruh media massa, khususnya televisi dalam meningkatkan popularitas para politikus.

\section{Kajian Literatur}

Penelitian tentang penggunaan media televisi untuk pencitraan politik bukanlah sesuatu yang baru. Tingginya konsumsi penggunaan televisi dibanding media massa lainnya, membuat masalah penggunaan televisi untuk memperbaiki citra politik menjadi sebuah kajian yang menarik untuk terus diamati. Di Amerika Serikat misalnya, studi tentang kemenangan presiden John F. Kennedy atas lawannya Richard Nixon pada tahun 1960 selalu dikaitkan dengan keberhasilan sang presiden memopulerkan dirinya melalui televisi. Berita-berita di televisi dan penampilan Kennedy pada saat debat kampanye berlangsung melalui televisi telah membuat jutaan rakyat Amerika Serikat berbondong-bondong datang ke tempat pemungutan suara untuk memberikan pilihan mereka pada Kennedy (Biagi, 2010).

Saat ini hampir tidak ada pencitraan partai politik atau tokoh politik yang akan mengikuti sebuah pemilihan jabatan politik yang tidak menggunakan media televisi. Karenanya, makin banyak kajian-kajian yang berkaitan dengan hal tersebut dilakukan banyak pakar komunikasi politik. 
Dampak dan manfaat media massa sudah sangat menjadi perhatian yang luas di kalangan peneliti media massa. Tidak heran banyak teori yang lahir dari pemanfaatan media massa, terutama televisi untuk pencitraan partai politik maupun tokoh politik, seperti teori agenda setting terus dikenal luas hingga saat ini (Severin \& Tankard, 2008).

Di Indonesia, riset tentang pemanfaat media televisi untuk pencitraan partai politik atau tokoh politik juga sudah menjadi kajian riset tersendiri meskipun hanya menyorot makna interaksi politik yang khas diperlihatkan anggota DPR. Terjadi kondisi yang sangat berbeda penampilan seorang politikus, ketika ada kamera dengan pada saat tidak ada kamera televisi. Hal itu jelas menunjukkan bahwa kehadiran media televisi amat diperhitungkan untuk meningkatkan citra politikus tersebut (Ariane, 2012).

Masih dalam kajian yang sama, pencitraan menjadi sebuah langkah politik yang wajib bagi seorang yang ingin terjun dalam jabatan politik publik. Dalam hal ini, penggunaan media televisi sudah amat luas dan harus diperhitungkan oleh para politikus untuk meraih dukungan dari masyarakat. Bahkan Nursal (2004), secara spesifik, melihat perlunya strategi yang tepat dalam penggunaan media telavisi, sehingga punya dampak positif yang kuat untuk dapat sukses dalam sebuah pemilihan jabatan politik publik tertentu tersebut.

Secara umum hasil penelitian tentang media dan pemilu baik memuat banyak penelitian tentang penggunaan media pada masa pemilihan umum, seperti Luwarso (2004). Beberapa juga menyangkut bagaimana media televisi mengangkat citra konstestan pemilu, baik partai politik maupun para politikus. Luwarso dkk (2004) banyak menyorot secara kritis, bagaimana media berperan dalam mengangkat citra partai politik atau politikus pada pemilu pada era reformasi tersebut. Kajian kritis ini bahkan telah membuka pergulatan menarik, bahwa selain punya dampak positif, banyak dampak negatif akibat penggunaan media, terutama televisi yang amat massif dalam pencitraan partai politik atau politikus tersebut (Luwarso, 2004).

Penggunaan media massa, terutama televisi bagi kegiatan politik tetap akan menjadi kajian yang menarik karena pada masa mendatang aktivitas tersebut makin banyak dilakukan. Meskipun sekarang mulai berkembang aktivitas sosial media, penggunaan televisi baik tidak berbayar maupun televisi berbayar akan tetap menjadi media utama kunci sukses seseorang dalam sebuah pemilihan politik. Seperti yang dikatakan pakar komunikasi politik, Jallaludin Rahmat dalam pengantar buku (Nimmo, 2006) menyatakan bahwa pesan politik melalui media massa, terutama televisi, akan berperan penting dalam pembahasan kajian pencitraan politik, baik di Indonesia maupun di dunia.

\section{METODE}

Penelitian menggunakan metode kualitatif untuk mendapatkan gambaran terhadap fenomena sosial yang terjadi, terutama yang berkaitan antara kerja politik para politikus di satu sisi dengan kemampuan media massa, khususnya televisi; di sisi lain, untuk meningkatkan elektabilitas atau tingkat keterpilihan dari politikus di sebuah pemilihan umum. Pengumpulan data dilakukan melalui studi pustaka, observasi dan dokumentasi. Studi pusataka atau literatur dilakukan tentang produksi kerja politik politikus, peran media massa khususnya televisi dalam pemilihan umum maupun permasalahan elektabilitas para politikus. Sementara, observasi dilakukan dengan melihat tontonan tayangan televisi pada saat pemilihan anggota legislatif. Terakhir, untuk dokumentasi dilakukan terutama terkait dengan data hasil survei tentang elektabilitas partai politik maupun politikus pada pemilihan legislatif lalu. 


\section{HASIL DAN PEMBAHASAN}

Peran televisi seperti juga peran media lainnya bukanlah faktor utama dan penentu dalam mengerek popularitas politikus. Apapun yang dilakukan media, termasuk televisi, hanyalah menjadi support atau pendukung dari upaya keseluruhan politikus untuk menaikkan pamor. Di luar penggunaan media, tentu saja televisi di dalamnya, para aktivis atau pekerja politik tersebut harus membangun kerja politik dan komunikasi politik secara keseluruhan yang baik dan terencana. Jangan berharap media ataupun televisi bisa menjadi satu-satunya alat untuk menaikkan citra atau nama politikus dari yang tidak terkenal untuk menjadi terkenal dan akan dipilih dalam sebuah kegiatan pemilihan umum. Lebih dari itu, diperlukan berbagai sinergi, termasuk upaya untuk memanfaatkan media dan televisi, guna menaikkan popularitas sehingga menjadi modal besar untuk terpilih dalam pemilu.

Tidak ada jalan pintas barangkali amat tepat untuk menggambarkan kiat sukses para politikus untuk meningkatkan popularitas. Penggunaan media televisi, tidak bisa langsung menyulap atau membalikkan telapak tangan jalan sukses bagi politikus menaikkan pamornya. Kerja politik, melakukan tindakan nyata untuk konstituennya, jelas modal awal, yang tidak tergantikan. Upaya untuk terus dekat, mendengar dan membela masyarakat dari berbagai permasalahan yang mereka hadapi sehari-hari menjadi langkah yang terus menerus dilakukan untuk tetap ada di hati rakyat. Kerja politik itu juga masih harus ditunjang dengan terus berlaku dalam tataran dan nilai-nilai yang berlaku dalam masyarakat setempat. Bukan tidak mungkin, kerja politik sekeras mungkin yang dilakukan rusak oleh nila setitik karena kesalahan dalam bertingkah laku atau melanggar norma, adat, atau agama yang juga sering dianggap sebagai parameter untuk menentukan baik atau tidaknya seseorang.

Tentu saja kerja politik yang konsisten dan terus berlaku dalam tataran dan nilai-nilai yang berlaku di masyarakat, yang dilakukan para politikus untuk menaikkan citra politik atau popularitas, juga perlu dikomunikasikan atau diinformasikan kepada masyarakat atau calon konstituen. Untuk itu, perlu juga dibangun komunikasi politik yang efektif dan efisien oleh para politikus atau partai politik yang menaungi mereka. Komunikasi politik yang efektif tentu dilakukan agar setiap tindakan konkret yang dilakukan para politikus tersebut dapat sampai diterima, didengar atau dilihat oleh masyarakat atau calon konstituen. Sementara, komunikasi politik yang efisien tentu dilakukan agar setiap komunikasi politik yang dilakukan, termasuk penggunaan televisi untuk menaikkan popularitas politikus tersebut, dapat tepat sasaran dan mendapat sambutan positif dari masyarakat atau calon konstituen. Dengan komunikasi politik yang efektif dan efisien, nantinya, para politikus tersebut berharap pada akhirnya popularitas mereka terus meningkat, sehingga mendapat pemilih yang banyak dalam pemilu mendatang.

Dalam sebuah pembekalan terhadap calon anggota DPR dari sebuah partai politik besar, beberapa politikus di partai tersebut sempat mempertanyakan kenapa media massa, termasuk televisi, menganakemaskan Jokowi, Gubernur DKI Jakarta, sehingga semua aktivitasnya diliput dan diberitakan televisi. Politikus partai besar tersebut menganggap karena pemberitaan besar-besaran di media yang pada akhirnya menjadi resep meroketnya popularitas Jokowi. Praduga tersebut memang tidak sepenuhnya salah, tetapi tetap ada juga yang harus diluruskan dari hipotesis tersebut. Nama Jokowi juga makin cepat berkibar karena pemberitaan yang ada di televisi memang tidak mungkin dipungkiri. Namun yang juga harus disadari, pemberitaan media massa tidak akan semasif demikian jika tidak ada langkah konkret atau wujud nyata yang dilakukan Jokowi untuk mengurus atau menyelesaikan permasalahan warga Jakarta yang dipimpinnya.

Barangkali yang juga kurang disadari oleh para politikus, wujud konkret atau tindakan yang nyata yang dilakukan Jokowi untuk mengurus warganya tersebut, sesuai dengan karakteristik media televisi yang mengutamakan visual atau gambar untuk menyampaikan pesannya. Dengan banyaknya 
gambar yang memperlihatkan aksi Jokowi blusukan atau menyelesaikan permasalahan Jakarta dengan tindakan nyata, jelas akan sangat menarik dibandingkan dengan kesukaan para politikus untuk melempar isu, menanggapi isu, atau mengomentari isu atau sekadar membuat pernyataan dalam sebuah konferensi pers, yang jelas-jelas hanya menjadikannya sebagai sebuah talking news, yang sebenarnya tidak begitu bagus dan cepat membosankan, jika ditayangkan di televisi. Dengan demikian, jika pun sering tampil di televisi, jika hanya talking news, belum tentu efektif dan efisien untuk menaikkan popularitas dari politikus tersebut.

\section{SIMPULAN}

Sebenarnya, langkah para politikus yang membangun komunikasi politik, dengan menggandeng media, karena mereka membutuhkan media, adalah paradigma lama, yang mungkin sudah usang dan perlu diganti. Sekarang, sudah saatnya para politikus berpikir untuk tidak lagi selalu hanya satu-satunya melalui media termasuk televisi, untuk menaikkan popularitas mereka. Seharusnya, pada saat ini, para politikus juga mulai berpikir, bagaimana caranya agar media, termasuk televisi yang memburu mereka atau membutuhkan mereka, untuk keperluan media atau televisi itu sendiri dan tentu saja untuk memenuhi keinginan khalayak media atau penontonnya. Sekarang, permasalahannya adalah bagaimana caranya agar media, termasuk televisi atau khalayak media atau penontonnya, yang membutuhkan para politikus itu sendiri.

Permasalahan jika Jokowi bisa, para politikus lainnya, harusnya juga bisa. Sekedar untuk menaikkan citra politik atau popularitasnya, tanpa kerja politik yang keras dan cerdas, tentu saja sudah menjadi lagu lama yang harus ditinggalkan. Sudah saatnya, para politikus harus membuat langkah konkrit dan nyata untuk membela kepentingan masyarakat atau konstituennya. Sudah saatnya pula, dibangun komunikasi politik, termasuk penggunaan media televisi, untuk menginformasikan atau mengkomunikasikan langkah konkrit yang dibuat agar sampai didengar, dilihat atau dirasakan masyarakat atau konstituennya. Tidak ada popularitas yang naik hanya karena pencitraan politik semata, tetapi popularitas akan meningkat dengan tindakan nyata dan komunikasi politik yang efektif dan efisien tentunya.

\section{DAFTAR PUSTAKA}

Arriane, L. (2010). Komunikasi Politik, Politikus dan Pencitraan di Panggung Politik. Bandung: Widya Padjajaran.

Biagi, S. (2010). Media/Impact: Pengantar Media Massa. Jakarta: Salemba Humanika.

Luwarso, L, dkk. (2004). Media dan Pemilu 2004. Jakarta: SEAPA.

Mitsikopu, L. B. (2008). Introduction the branding of political entiteses discuoursive practice. Journal of Languenge and Politics, 7(3), 353-371.

Nimmo, D. (2006). Komunikasi Politik: Khalayak dan Efek. Bandung: Remaja Rosdakarya.

Nursal, A. (2004). Political Marketting: Strategi Memenangkan Pemilu, Sebuah Pendekatan Baru Kampanye Pemilihan DPR, DPD, Presiden. Jakarta: Gramedia Pustaka Utama.

Severin, W. J. \& Tankard, J. W. (2008). Teori Komunikasi, Sejarah Metode dan Terapan di Dalam Mediia Massa. Jakarta: Kencana. 